\title{
RAISING TAXES THROUGH EQUALIZATION
}

\author{
MICHAEL SMART \\ CESIFO WORKING PAPER No. 1926 \\ CATEgORY 1: Public FinANCE \\ FEBRUARY 2007
}

An electronic version of the paper may be downloaded

- from the SSRN website:

www.SSRN.com

- from the RePEc website:

www.RePEc.org

- from the CESifo website:

www.CESifo-group.de 


\title{
RAISING TAXES THROUGH EQUALIZATION
}

\begin{abstract}
A simple theory suggests that a common form of federal horizontal equalization grants should cause subnational governments to levy higher tax rates, distorting local tax bases and so increasing federal transfers. To test this, I examine Canadian provincial tax policies in the 1972-2002 period. Consistent with the theory, provinces respond to expansions of equalization transfers by increasing their own tax rates. I estimate that on average tax rates in grant-receiving provinces were substantially and significantly higher as a consequence of the transfer formula.
\end{abstract}

JEL Code: H21.

\author{
Michael Smart \\ Department of Economics \\ University of Toronto \\ 150 St. George St. \\ Toronto ON M5S $3 G 7$ \\ Canada \\ msmart@economics.utoronto.ca
}

Revised Version: September 13, 2006

Thanks to Pierre Doucet and Michelle Taylor of the federal Department of Finance for access to and assistance with data, to Peter Egger, Jim Hines, Nicolas Marceau and Wolfram Richter for comments, and to faculty and staff of Center for Economic Studies Munich, where this paper was written. 


\section{Introduction}

Most federations employ a system of "horizontal" equalization grants of one kind or another, which seeks to redistribute fiscal resources among subnational governments in the nation. The goal of such transfers is to permit all subnational governments to gain access to similar fiscal resources while imposing similar tax burdens on local residents. ${ }^{1}$ In the most common such system, known as a capacity equalization or foundation grant, each government receives a transfer equal to the difference between its measured tax base and the average base of all regions, multiplied by some target tax rate. Thus a capacity equalization grant insures that each jurisdiction can achieve some target level of spending determined by federal authorities, as long as it sets its own tax rate at least as high as the target level.

The capacity equalization principle currently forms the basis for transfer systems in Australia, Canada, Germany, and Switzerland, as well as local school district finance formulas in a number of US states (Card and Payne, 2002). An apparent advantage of the approach is that each government's transfers are defined as a function of local measured tax bases, but not of local revenues themselves. In contrast, a system of direct revenue sharing often creates a common pool problem among local governments that is apt to reduce tax effort (Baretti et al., 2001).

Nevertheless, Smart (1998) observed that capacity equalization may distort local tax policies as well-but causing local governments to levy higher rather than lower tax rates. The argument is straightforward: increasing distortionary local tax rates causes measured tax bases to decline, as economic activity shifts to other regions of the country or to other, more lightly taxed formsand so causes capacity equalization transfers to rise. Thus the grants in effect compensate for a portion of the marginal deadweight loss of tax increases. This effect is clearest when considering a receiving province with a tax rate equal to the target tax rate at which capacity deficiencies are compensated: At this point, further increases in the rate will appear to create no deadweight loss to the province, as the increase in equalization transfers exactly compensates for marginal losses in private consumption. Thus equalization tends to drive tax rates above the target tax rate. ${ }^{2}$ (In Section 2 below, I offer a formal statement of this idea.)

An emerging empirical literature provides some evidence of the tax-raising effects of capacity equalization. Boadway and Hayashi (2001) report that provinces in Canada that receive equalization are more inclined than others to raise business tax rates when the national average rate goes up, as the theory predicts. Esteller More and Sole Olle (2002) find a similar effect for personal tax rates in Canada too. Dahlby and Warren (2003) report that equalization grants induce higher levels of taxation by state governments in Australia, and Buettner (2005) and Egger et al. (2006) find the same for the municipal business taxes that are equalized in many German states.

In this paper, I seek to establish further evidence of the tax-raising effects of equalization, by taking a more comprehensive perspective on the data and adopting different identification strategies than in the previous literature. Using Canadian administrative data for the 1972-2002 period, I examine provincial tax decisions in most of the (about 30) revenue categories that are subject to

\footnotetext{
${ }^{1}$ Such equalizing transfers evidently serve a central role in achieving horizontal equity among regions, and in the presence of fiscally induced migration they may also be required to achieve a Pareto efficient allocation of resource among regions (Boadway and Flatters, 1982). See for example Bird and Smart (2002) for an overview of the theory and practice of intergovernmental transfers.

${ }^{2}$ A related literature deals with the "flypaper effect" of federal grants-the finding that categorical grants to subnational governments typically do not induce the reductions in local tax rates that elementary theory predicts; see Knight (2002) for a recent contribution. That literature deals with the income effects of grants, whereas the effect of equalization on tax rates is in the nature of a "price effect".
} 
equalization in Canada. The data and the relevant institutions are discussed in detail in Sections 3 and 4 of the paper.

To establish the causative impact of the transfers on subnational taxes, I take two approaches.

First, in Section 5, I follow Boadway and Hayashi (2001) in estimating tax reaction functions for my more comprehensive data set, and compare how recipient and non-recipient provinces respond to changes in the target tax rate. Since the target rate in Canada is in fact the average of contemporaneous provincial tax rates, this raises a simultaneity problem, which I attempt to solve by using instrumental variables for the target tax rate. Based on the IV estimates, and consistent with the theory, I find that increases in the national average tax rate cause significant increases in tax rates of grant-receiving provinces, but not of other provinces.

Second, in Section 6, I exploit reforms in Canadian equalization grant program, which varied the rate at which natural resource capacity differentials have been equalized in the past. Since formula parameters vary in an arguably orthogonal way among revenue categories and provinces, and over time, the data therefore admit a "triple-difference" estimator of the effect of the formula. These estimates imply that an increase in the fraction of capacity differences equalized from 50 per cent to 100 per cent causes an increase in local tax rates of about seven percentage points. Interestingly, rough calculations based on the the structural estimates of Section 5, reported in the concluding Section 7, also suggest that halving the rate of equalization to 50 per cent would reduce tax rates in the affected provinces by about seven percentage points. On the basis of both estimation strategies, therefore, there is evidence of a robust and substantial tax-raising effect of equalization grants.

\section{Equalization and tax competition}

To understand how equalization grants affect tax interactions among governments, consider a simplified version of the model in Bucovetsky and Smart (2006). A federation consists of $N$ jurisdictions, each with a single tax base, and with a fraction $\omega_{i}$ of the national population. Jurisdiction $i$ levies tax rate $y_{i}$ on its own per capita tax base $B_{i}$, and it receives a per capita equalization grant equal to $\theta \bar{y}\left(\bar{B}-B_{i}\right)$, where $\bar{y}$ is the target tax rate, $\bar{B}$ the target or standard fiscal capacity chosen by federal authorities, and $\theta$ the fraction of capacity differences $\bar{B}-B_{i}$ that is equalized. This formulation evidently subsumes the important polar cases of no equalization grants $(\theta=0)$ and full equalization of capacity differences $(\theta=1)$.

Let the tax base in each jurisdiction $i$ be an identical linear function of tax rates in the federation,

$$
B_{i}=B^{0}+b \bar{y}_{-i}-a y_{i}
$$

where

$$
\bar{y}_{-i}=\frac{1}{1-\omega_{i}} \sum_{j \neq i} \omega_{j} y_{j}
$$

is the population-weighted average of tax rates in competing jurisdictions, and $B_{i}^{0} \geq 0$ and $a>b \geq$ 0 are parameters. Thus the model incorporates a fiscal spillover among jurisdictions when $b>0$, since tax rate increases by one jurisdiction cause tax base increases in the others.

From this formulation, it is apparent that increases in a jurisdiction's own tax rate cause declines in its tax base, and tax base declines induce greater equalization transfers. Thus a government 
seeking to maximize revenues net of equalization transfers ${ }^{3}$ optimally chooses a higher tax rate in the presence of equalization than it otherwise would. Moreover, this tax-raising effect is larger, the larger is the effective "subsidy rate" $\theta \bar{y}$ for capacity declines.

The analysis is complicated by the fact that, in most equalization programs, the target tax rate and standard fiscal capacity are functions of the actual tax rates and tax bases of jurisdictions, and so are endogenous to $y_{i}$. A "sophisticated" government will recognize this dependence and adjust its optimal tax rate accordingly. To solve for optimal tax policies with equalization, then, let $\bar{y}$ and $\bar{B}$ be population-weighted means of tax rates and tax bases, respectively:

$$
\begin{aligned}
& \bar{y}=\sum_{i=1}^{N} \omega_{i} y_{i} \\
& \bar{B}=\sum_{i=1}^{N} \omega_{i} B_{i}
\end{aligned}
$$

The equalization entitlement of jurisdiction $i$ can then be expressed, using (1) and (3), as

$$
E_{i}=\theta \bar{y} c_{i}\left(y_{i}-\bar{y}_{-i}\right)
$$

where $c_{i}=\omega_{i} b+\left(1-\omega_{i}\right) a$ is a function of parameters.

The tax rate $y_{i}^{*}$ that maximizes net revenues thus solves

$$
\max y_{i} B_{i}\left(y_{i}, \bar{y}_{-i}\right)+\theta \bar{y} c_{i}\left(y_{i}-\bar{y}_{-i}\right)
$$

subject to

$$
\bar{y}=\omega_{i} y_{i}+\left(1-\omega_{i}\right) \bar{y}_{-i}
$$

The first-order (necessary and sufficient) condition may be expressed as

$$
y_{i}^{*}\left(\bar{y}_{-i}, \theta\right)=\alpha_{i}(\theta)+\beta_{i}(\theta) \bar{y}_{-i}
$$

where

$$
\begin{aligned}
\alpha_{i}(\theta) & =\frac{B^{0}}{2 a-2 \theta \omega_{i} c_{i}} \\
\beta_{i}(\theta) & =\frac{b+\theta c_{i}-2 \theta \omega_{i} c_{i}}{2 a-2 \theta \omega_{i} c_{i}}
\end{aligned}
$$

Thus each government's optimal tax rate is a linear function of the average tax rate in competing jurisdictions, and equalization grants (indexed by $\theta$ ) affect both the intercept and slope of the reaction function. ${ }^{4}$

To understand how equalization grants affect tax setting and the strategic interaction between competing governments, differentiate (4) with respect to the fraction of revenues equalized $\theta$ to obtain

$$
\frac{\partial y_{i}^{*}\left(\bar{y}_{-i}, \theta\right)}{\partial \theta}=\frac{c_{i}}{a-\theta \omega_{i} c_{i}}\left[\omega_{i} y_{i}+\left(\frac{1}{2}-\omega\right) \bar{y}_{-i}\right] \geq 0 \quad \text { since } \omega_{i} \leq \frac{1}{2}
$$

\footnotetext{
${ }^{3}$ The revenue-maximization assumption is inessential; the case of welfare maximizing governments is addressed in Smart (1998), and the qualitative results are the same.

${ }^{4}$ Observe that $y_{i}^{*}>0$ for all $\theta \in[0,1]$, since $a>b$.
} 
Differentiating again with respect to $\bar{y}_{-i}$ likewise shows that

$$
\frac{d}{d \theta} \frac{\partial y_{i}^{*}\left(\bar{y}_{-i}, \theta\right)}{\partial \bar{y}_{-i}}=\beta_{i}^{\prime}(\theta) \geq 0
$$

Thus we have:

Proposition 1 An increase in the fraction of revenues equalized $\theta$ causes an increase in the bestresponse tax rate $y_{i}^{*}$, and an increase in strategic complementarity of tax rates $\left(y_{i}, y_{j}\right)$.

That is, equalization grants cause recipient governments not only to raise tax rates, but also to increase their (here positive) response to tax rate increases of competitors. Thus, as shown by Köthenbürger (2002) and Bucovetsky and Smart (2006) in somewhat different models, equalization serves to attenuate the "race to the bottom" in tax rates that may result from tax competition.

In the empirical exercise that follows, we will be especially interested in distinguishing tax setting behaviour of governments that receive equalization grants from those that do not. Accordingly, let

$$
y_{i}^{0} \equiv \alpha_{i}(0)+\beta_{i}(0) \bar{y}_{-i}=\frac{B^{0}}{2 a}+\frac{b}{2 a} \bar{y}_{-i}
$$

denote the reaction function in the absence of grants, and

$$
y_{i}^{1} \equiv \alpha_{i}(1)+\beta_{i}(1) \bar{y}_{-i}=\frac{B^{0}}{2\left(a-\omega_{i} c_{i}\right)}+\frac{b+c_{i}-2 \omega_{i} c_{i}}{2\left(a-\omega_{i} c_{i}\right)} \bar{y}_{-i}
$$

denote the reaction function given full equalization of capacity differences. The empirical work in Section 5 provides estimates of the difference in slopes of reaction functions for equalization receiving and non-receiving provinces,

$$
\Delta_{i} \equiv \beta_{i}(1)-\beta_{i}(0)=\frac{\left(1-2 \omega_{i}\right) a c_{i}+\omega_{i} b c_{i}}{2 a\left(a-\omega_{i} c_{i}\right)}
$$

Observe that, consistent with Proposition $1, \Delta_{i}>0$; thus the main hypothesis to be tested is that strategic complementarity of tax rates is greater for equalization-receiving than non-receiving provinces. The magnitude of this effect depends on the tax base parameters $a$ and $b$ in general, but setting $\omega_{i}=0$ in (7) implies $\Delta_{i}=1 / 2$ for all $(a, b)$. Thus, for provinces with small population, the effect of equalization on complementarity are similar for all provinces and tax bases, and approximately equal to one-half.

\subsection{Equilibrium and efficient taxation}

In Section 6 of the paper, I present estimates of the reduced-form effect of the equalization rate $\theta$ on the tax rates of receiving and non-receiving provinces. These reduced-form estimates correspond to the Nash equilibrium of the theoretical model. Characterizing Nash equilibrium tax rates and how they depend on the equalization rate is complicated in general, because of the aforementioned dependence of each jurisdiction's tax rate on its population share. But the main insights of the model can be obtained by considering the limiting case in which each jurisdiction's population share is zero, so that its reaction function is a common function $y^{*}\left(\bar{y}_{-i}, \theta\right)$. Letting $y^{R}$ and $y^{N}$ 
denote the equilibrium tax rates in receiving and non-receiving provinces, respectively, solving for the fixed point of reaction functions (4) in the limiting case implies

$$
y^{R}(\theta)-y^{N}(\theta)=[\alpha(\theta)-\alpha(0)]+[\beta(\theta)-\beta(0)] \bar{y}^{*}(\theta)
$$

where $\bar{y}^{*}(\theta)$ is the population-weighted average of the two Nash equilibrium tax rates, given $\theta$. Applying Proposition 1, each term on the right-hand side of this expression is increasing in $\theta$. Noting that equilibrium tax rates are continuous functions of population shares, we have:

Proposition 2 When jurisdictions' population shares are small, an increase in the equalization rate $\theta$ causes an increase in equilibrium tax rates of receiving provinces, relative to those of non-receiving provinces.

That is, the testable hypothesis is that an increase in the rate at which capacity differences are equalized causes an increase in the difference in tax rates $y^{R}-y^{N}$. (Both $y^{R}$ and $y^{N}$ will increase when tax rates are strategic complements.)

In the empirical work below, I seek to establish that equalization transfers increase affected tax rates, in the sense of both Propositions 1 and 2. But drawing policy inferences from such a conclusion requires one to evaluate the efficiency properties of the resulting equilibrium tax rates. In the partial equilibrium theoretical model of Smart (1998), the tax-raising effect of equalization results in equilibrium tax rates that are above second-best optimal levels, and so a loss in welfare for consumers. But in the general equilibrium context of horizontal tax competition considered here, inducing jurisdictions to set higher tax rates may or may not be desirable from a national perspective.

It is a straightforward matter to determine the effect of equalization grants on welfare in this model. Consider a somewhat simpler environment, in which all jurisdictions in the federation receive equalization transfers (a "net scheme"), and all have equal populations. Solving again for the (now symmetric) fixed point of the reaction functions (4), the equilibrium tax rate, given the equalization rate $\theta$, is:

$$
\bar{y}^{*}(\theta)=\frac{B^{0}}{2 a-b-\theta c}
$$

where $c=\omega b+(1-\omega) a$ as before.

A tax policy that is Pareto efficient from a national perspective is any $\left(y_{1}, \ldots, y_{N}\right)$ which maximizes national revenues $\sum y_{i} B_{i}$, together with desired lump-sum transfers between the jurisdictions. The reader may easily verify that any such efficient allocation must have a uniform tax rate in all jurisdictions, so that we may equivalently choose a national tax rate $\bar{y}$ to maximize $\bar{y} \bar{B}(\bar{y})$, yielding

$$
\bar{y}^{e}=\frac{B^{0}}{2 a-2 b}
$$

as the unique Pareto efficient national tax rate.

Equating the two tax rate expressions, one sees that $\bar{y}^{*}(\theta)=\bar{y}^{e}$ if and only if $\theta c=b$, or

$$
\theta=\theta^{*} \equiv \frac{b}{\omega b+(1-\omega) a} \in[0,1)
$$

Furthermore, since revenue is a concave function of the tax rate, we have:

Proposition 3 An increase in the equalization rate $\theta$ causes an increase in equilibrium national welfare if and only if $\theta<\theta^{*}$. 
A grant that equalizes a fraction $\theta^{*}$ of capacity differences is therefore a Pigouvian corrective device for tax competition, which decentralizes the Pareto optimal allocation. Naturally, the optimal degree of equalization depends on the extent of interjurisdictional mobility of the tax base, parameterized by $(a, b)$, and hence the degree of tax competition. In particular, suppose that $b \rightarrow a$, so that the national aggregate tax base is asymptotically independent of tax rates-a tax cut by one jurisdiction merely diverts tax base from the rest of the federation. Then $\theta^{*} \rightarrow 1$ : full equalization of tax base deficiencies is optimal in the limit. At the other extreme, when $b=0$ and $a>0$, so that there is no interjurisdictional mobility, but taxes have distortionary effects within the jurisdiction, then $\theta^{*}=0$ : an equalization grant serves no corrective role, and any positive $\theta$ result in equilibrium tax rates in excess of the Pareto efficient level.

The $a=b$ case, in which tax bases are perfectly inelastic nationally, but nonetheless mobile between jurisdictions of the federation, is no doubt extreme, and the rather Panglossian conclusion that a full equalization grant is also an optimal Pigouvian subsidy is therefore inaccurate in general. Indeed, on the basis of the estimates reported below, one may reach rather stark conclusions about the inefficiency of equalization payments in Canada. I return to this assessment in the final section of the paper.

\section{Equalization grants in Canada}

The federal government in Canada has since 1957 operated capacity equalization grants for the ten Canadian provinces on the basis of the so-called Representative Tax System (RTS). The RTS system is designed to allow provinces to obtain the same fiscal resources when they levy the same tax rates, despite differences in the sizes of their tax bases. It pays provinces an amount, in respect of each revenue source defined in the system, equal to the deficiency, relative to a standard level, in the revenues it could collect from each measured base, if it levied the average of all provinces' tax rates. At present, this calculation is done for 33 separate revenue sources, and the standard tax base is set equal to the population-weighted average of per capita tax bases in a subset of five provinces. Equalization entitlements are then summed over the 33 categories and, if the total is positive, the province is paid its entitlement, subject to provisions that are intended to smooth changes in payouts for both federal and provincial governments. A province with a negative net entitlement receives a net transfer of zero; thus equalization is on a "gross" rather than "net" basis, and aggregate transfers are financed from general federal tax revenues, rather than through contributions imposed on high-capacity provinces.

In algebraic terms, the equalization formula is a slightly more complex version of that considered in Section 2: Consider revenue source $j$, for which each province $i$ has a measured tax base $B_{i j}$ and collects revenues subject to equalization $R_{i j}$. Let $N_{i}$ be the population of each province. Let $R_{j}=\sum_{i} R_{i j}, B_{j}=\sum_{i} B_{i j}$, and $N=\sum_{i} N_{i}$ be the national aggregates of provincial revenues, tax bases, and population, and $B_{s j}=\sum_{i \in S} B_{i j}$ and $N_{s}=\sum_{i \in S} N_{i}$ be the corresponding aggregates for the five standard provinces. The RTS system calculates the national average effective tax rate $\bar{y}_{j}=R_{j} / B_{j}$ and determines the standard per capita tax base $B_{s j} / N_{s}$. The equalization entitlement of each province $i$ in respect of revenue category $j$ is then

$$
E_{i j}=\bar{y}_{j}\left(\frac{B_{s j}}{N_{s}}-\frac{B_{i j}}{N_{i}}\right) N_{i}
$$

That is, each province's entitlement equals its deficiency in per capita tax base, multiplied by the 
national average tax rate and by its population. Each province then receives an aggregate transfer

$$
E_{i}^{*}=\max \left\{\sum_{j} E_{i j}, 0\right\}
$$

That is, if the aggregate of entitlements for all revenue sources is positive, the province is termed a "receiving province" and is paid its entitlement; otherwise, the province is "non-receiving" and is paid zero.

While equalization grants have been paid on an RTS basis in Canada since 1957, the specifics of the transfer formula are adjusted often, and the enabling legislation for the transfers is re-enacted every five years by the federal government. The quinquennial reforms have dealt primarily with the number and definition of revenue sources used in the formula, and the data sources and measurement techniques used to construct proxies for revenue capacities, where direct measurement of the relevant tax bases is impossible. For example, since 1992 each province's tax base for Forestry Revenues has been defined as the volume in cubic metres of wood cut on government-owned land during the year, replacing an earlier definition based on annual estimates of industrial value added in each province. The most significant such reform took place in 1982, when the number of revenue categories was increased to 33 from 29 and the standard tax bases $B_{s j}$ were defined to be the aggregate tax base of the five "standard" provinces rather the previous national average standard. ${ }^{5}$

Such technical changes in tax base measurement pose a challenge for the empirical work that follows, since changes in effective provincial tax rates calculated from administrative data may merely reflect base redefinitions, rather than real changes in provincial tax policies. I describe my strategy for dealing with this problem in the next section.

Many of the changes to the formula have related to oil, natural gas, and other resource revenues of the provinces-no doubt reflecting the great inequality in the distribution of these revenues among the provinces and consequently the high fiscal cost to the federal government of equalizing them on a gross basis. In particular, in response to the increase in world energy prices (and hence in provincial revenues) in the 1970s, the federal government has introduced a number of reforms to the program that have altered the fraction of provincial resource revenues subject to equalization. Beginning in 1974, the fraction of incremental energy revenues equalized was reduced to one-third from 100 per cent; however, so-called "basic" energy revenues-those deemed to be available at pre-1973 energy prices-continued to be fully equalized. In the 1977 reform, the basic-incremental distinction was abandoned, and 50 per cent of all provincial revenues from non-renewable natural resources were made subject to equalization. In 1982, the federal government returned to 100 per cent equalization of resource revenues, but as discussed above the standard level of revenue capacity was adjusted downward in order to keep aggregate transfers roughly the same. Full equalization of all revenue categories to the lower standard has remained in place since 1982.

The reforms have however had little impact on the set of provinces eligible to receive Equalization, which has remained very stable over time. In the 1972-2002 sample period for my data set, six provinces received Equalization grants in all years, and one additional province (Saskatchewan) received grants in all but five of the sample years. My estimates of the effects of the grants are therefore driven by differences in observed behaviour of receiving and non-receiving provinces, rather than (potentially endogenous) changes in behaviour coincident with changes in eligibility.

\footnotetext{
${ }^{5}$ The five standard provinces are Quebec, Ontario, Manitoba, Saskatchewan, and British Columbia; the previous standard also included the energy-rich province of Alberta and the four provinces on the Atlantic seaboard. The apparent goal of the reform was to reduce the sensitivity of aggregate transfers to changes in energy prices and hence in Alberta's revenue capacity.
} 


\section{Data and estimation}

The principal source of data for the analysis is an administrative data set recording tax bases and revenues of the 10 provinces for the 1972-2002 period-excluding 1973 and 1981, when tax base data are missing - which is used by the federal Department of Finance to compute each province's transfer entitlements under the Equalization program. The ratio of tax revenues to tax base for each province, year, and revenue category defines the respective effective tax rate, which is the dependent variable for the analysis.

Naturally, measurement of the appropriate base for each provincial revenue source is a difficult and sometimes subjective process, and a small number of the measured bases in the administrative data bear little relation to the underlying economic activity from which the revenues are derived. For example, the measured tax base for residential and commercial property taxes is a modified measure of provincial personal income, rather than an estimate of the value of the stock of assets. In such cases, I excluded the revenue category from the analysis a priori; a full list of these exclusions is given in the data appendix. A related concern is technical changes in the measurement of tax bases during the sample period, which give rise to changes in the constructed average effective tax rates that are unrelated to the underlying tax policies of the provinces. My data for the 1972-86 period are all measured on a consistent basis, since tax bases were recalculated retrospectively for all preceding years at the time of the 1982 reforms. For the 1987-2002 period, however, some measurement changes occurred. As noted above, for example, since 1992 each province's tax base for Forestry Revenues has been defined as the volume in cubic metres of wood cut on governmentowned land during the year, replacing an earlier definition based on annual estimates of industrial value added in each province. My strategies for dealing with measurement changes are described further below. After the a priori exclusions, there are 27 revenue categories recorded for at least some of the 29 years in the sample; when a province has no recorded tax base in a category, the corresponding tax rate is treated as missing. As a result, there is a total of 6017 observations in the unbalanced panel. Summary statistics for the revenue categories used in regression analysis are given in Table A1 of the appendix.

The theory set out in Section 2 advances two propositions about the tax-raising effects of equalization grants. First, equalization increases the strategic complementarity of competitors' tax rates. Second, an increase in the fraction of revenues equalized through the formula causes an increase in the tax rates set by receiving governments, relative to non-receiving governments. Both propositions are amenable to empirical tests with the data set.

To test the first proposition, I estimate equations of a form analogous to (5)-(6): ${ }^{6}$

$$
E T R_{i t c}=\alpha_{i}+\delta_{t}+\gamma_{c}+\beta_{0} A T R_{i t c}+\left(\beta_{1}-\beta_{0}\right) A T R_{i t c} \times R C V_{i}+X_{i t}^{\prime} \theta+\epsilon_{i t c}
$$

where $E T R_{i t c}$ is the effective tax rate for province $i$, year $t$, and revenue category $c, A T R_{i t c}$ is the population-weighted average of the same tax rates in the other nine provinces, $R C V_{i}$ is an indicator variable for Equalization-receiving provinces, $X_{i t}$ is a vector of other explanatory variables, $(\alpha, \delta, \gamma)$ are vectors of fixed effects for provinces, years, and categories, and $\left(\beta_{0}, \beta_{1}, \theta\right)$ are other parameters to be estimated. The controls in $X$ are, as in much empirical research on tax setting, provincelevel economic, political, and demographic variables, including GDP per capita, the percentage of

\footnotetext{
${ }^{6}$ In the theoretical model, the coefficients $\beta_{0}$ and $\beta_{1}$ may in principle differ among revenue categories and provinces, so that the empirical estimates should be construed as average tax interaction effects for the sample. As noted in Section 2 , the equalization tax interaction effect $\beta_{1}-\beta_{0}$ is predicted to be near one-half for all provinces of small population, regardless of the of tax base parameters, so that heterogeneity of tax interaction effects should be small.
} 
the population under age 19 (Young), the percentage over age 64 (Old), and indicator variables for years in which the provincial government is controlled by right-leaning (Conservative) and left-leaning (Social democratic) political parties. ${ }^{7}$ The data on the control variables is taken from official Statistics Canada sources.

Under the equalization tax-interaction hypothesis, $\beta_{1}-\beta_{0}>0$ : equalization-receiving provinces should respond more positively to tax rate increases of other provinces than do non-receiving provinces. $^{8}$ Since fixed effects are included in (11), $\beta_{1}-\beta_{0}$ is identified from the differing response of receiving and non-receiving provinces to changes in ATR over time. ${ }^{9}$ Furthermore, the hypothesis that $\beta_{0}=0$ may be construed as a test of the notion that there are on average no tax interactions among governments-and so no tax competition-except for those induced by the Equalization formula.

Estimation of (11) is complicated by the possibility that tax rates in the various revenue categories are contemporaneously correlated among provinces, so that $E\left(\epsilon_{i t c} \mid A T R_{i t c}\right) \neq 0$ and OLS estimates are biased. To address this possibility, I adopt an instrumental variables strategy, in which the population-weighted averages of a subset of the explanatory variables $Z_{j t c}, j \neq i$, are used as instruments for $A T R_{i t c}$. That is, in the usual two-stage interpretation of the estimation procedure, $A T R_{i t c}$ and $A T R_{i t c} \times R C V_{i t}$ are projected onto $X_{i t c}$, the vectors of fixed effects, and the instruments

$$
\bar{Z}_{\tilde{i} t c}=\frac{\sum_{j \neq i} P O P_{j t} Z_{j t c}}{\sum_{j \neq i} P O P_{j t}}
$$

where $Z_{j t c}$ is a subvector of $X_{j t c}$. The particular instruments I choose are (the population-weighted averages of) Conservative, Social democratic, and Old for the other nine provinces.

The other part of Proposition 1, that equalization increases the intercept of reaction functions, is not amenable to testing with the Canadian data, because the set of Equalization-receiving provinces is nearly unvarying over the sample period. ${ }^{10}$ Consequently, $\mathrm{RCV}_{i}$ is collinear with the province fixed effects, and it is excluded from the regression.

The second theoretical proposition, concerning the effects of partial equalization on the level of taxes, has the virtue of being amenable to test in a reduced form specification, by exploiting the variation in the fraction of natural resource revenue differences that were equalized during the 1970s (see Section 3). Again, the empirical approach is one of "differences in differences," based on comparison of the changes in tax rates of receiving and non-receiving provinces following the return to full equalization in 1982. Of course, the oil shocks of the 1970s had far-reaching economic impacts, which might in principle differ between receiving (generally poor) and nonreceiving (rich) provinces in Canada, and which would therefore bias the difference-in-difference

\footnotetext{
${ }^{7}$ The conservative parties in power provincially during my sample period are those known as the Progressive Conservative and Social Credit parties. The social democratic parties are those known as the New Democratic Party and the Parti Quebecois. The excluded category is the centrist Liberal party.

${ }^{8}$ As noted in Section 3, the Canadian formula has since 1982 used an average of only five of the ten provinces' tax bases to measure the standard capacity level. However, the target tax rate remains defined as the average of all ten provinces' effective tax rates. The equalization effect should therefore be manifested in the response of ETR to ATR, the average of the nine other provinces' tax rates.

${ }^{9}$ The specification uses variation in ATR among revenue categories to estimate $\beta_{1}-\beta_{0}$, and so assumes there are no interactions among revenue categories, as opposed to among provinces, due to substitution patterns of taxpayers or income effects on government policies. Note however that income effects are likely negligible, since most revenue categories are a small share of total revenues.

${ }^{10}$ One receiving province, Saskatchewan, did not receive Equalization payments during the 1982-86 period, due to the effect of high energy prices on its measured fiscal capacity. To avoid dealing with the resulting problems of non-linearity and endogeneity, I simply delete all observations for Saskatchewan in these five years.
} 
estimates. In this case, however, a natural control is available in the observed tax rates of the two groups of provinces for the non-resource revenue categories, for which there were no changes in the rate of equalization under the formula during the sample period. I therefore estimate the effect of partial equalization from a "triple difference" specification. Define $\mathrm{RCV}_{i}$ as an indicator variable for equalization-receiving provinces, $\mathrm{RESOURCE}_{c}$ as an indicator for the resource categories affected by the grant reform, and PARTIAL $t$ as an indicator for the years 1974-1980 when the partial equalization system applied. An estimate of the effect of partial equalization is then the OLS estimate of $\gamma$ from the specification:

$$
\begin{gathered}
\text { ETR }_{i t c}=\alpha_{0}+\alpha_{1} \mathrm{RCV}_{i}+\alpha_{2} \mathrm{RESOURCE}_{c}+\alpha_{3} \text { PARTIAL }_{t} \\
+\beta_{1} \mathrm{RCV}_{i} \times \mathrm{RESOURCE}_{c}+\beta_{2} \mathrm{RCV}_{i} \times \mathrm{PARTIAL}_{t}+\beta_{3} \mathrm{RESOURCE}_{c} \times \mathrm{PARTIAL}_{t} \\
+\gamma R C V_{i} \times \mathrm{RESOURCE}_{c} \times \mathrm{PARTIAL}_{t}+\epsilon_{i t c}
\end{gathered}
$$

Since (12) includes the full set of bilateral interactions between the treated provinces $\mathrm{RCV}_{i}$, the affected revenue categories RESOURCE ${ }_{c}$, and the pre- and post-reform years PARTIAL $_{t}$, identification of the treatment effect $\gamma$ is based only on the assumption that there were no unobserved shocks contemporaneous with the reform that affected resource tax rates relative to non-resource tax rates in equalization-receiving provinces, and that did not similarly affect relative tax rates in the non-receiving provinces. In particular, this approach controls for unobserved effects of the 1973 oil shock (largely coincident with the partial equalization period) on resource tax rates of all provinces relative to non-resource taxes, and on all tax rates of receiving provinces relative to non-receiving provinces.

Because (12) is a reduced form specification of the effects of equalization on taxes, the resulting estimate of $\gamma$ is interpreted as the treatment effect of partial equalization on the Nash-equilibrium tax rates of receiving provinces derived from the reaction functions (4), relative to the effect on Nash-equilibrium tax rates of non-receiving provinces. That is, the estimation equation corresponds to the difference in equilibrium tax rates in equation (8), and Proposition 2 implies the testable hypothesis $\gamma>0$. In practice, as we will see, there is little evidence of a feedback from tax rates of receiving provinces to those of non-receiving provinces - the data are consistent with the only interaction in tax-setting coming from the equalization grant, rather than from inter-jurisdictional tax competition per se. Assuming no feedback effect of the reform on non-receiving provinces, then, the estimate of $\gamma$ may be interpreted as the combined effect of the reform on the slope and intercept of the reaction functions of grant-receiving provinces. I offer further interpretation of the coefficient in Section 7.

\section{Tax interaction effects of equalization}

I begin in Table 1 with OLS estimates of the tax-interaction (or slope) effect of equalization, estimated from the empirical version of the reaction function given in equation (11). All specifications in the table include fixed effects for each province, year, and revenue category in the pooled data set, the estimates of which are not reported. ${ }^{11}$ The reported estimated standard errors are robust to heteroskedasticity and arbitrary correlations among the vector of tax rates for a particular province

\footnotetext{
${ }^{11}$ I also include separate dummy variables for the personal income tax category in Quebec and the other provinces after 1976. This controls for the effects of the 1977 transfer of tax powers from the federal government to the provinces, which increased provincial taxes more in Quebec than other provinces.
} 
and year, which are the dimensions inducing exogenous variation in $\mathrm{ATR}_{i t c}$, the main right-hand side variable of interest.

The first column reports results estimated from the full data set, including all 27 revenue categories. Observe that the effect of average competitors' tax rates ATR is large and significantly different from zero at the one per cent significance level. For non-receiving provinces, indicated by $\mathrm{RCV}=0$, the point estimate of the effect is 0.69 , and for receiving provinces $(\mathrm{RCV}=1)$, the point estimate is significantly higher at 1.13. The demographic variables YOUNG and OLD are insignificant in this specification, perhaps because the principal impacts of demographic differences are absorbed by the province and year fixed effects. However, GDP per capita (measured in thousands of 1992 dollars per year) is significantly negatively related to tax rates in the OLS estimates, while presence of either Conservative or Social Democratic provincial governments is associated with somewhat higher taxes than under centrist Liberal governments, the excluded category.

As discussed in Section 4, tax bases for the revenue categories are measured in a variety of units, and some of the base definitions in the administrative data seem rather arbitrary. The principal control for the different units of the specific tax rates is the estimated fixed effects for each revenue category. Moreover, ETR and ATR are measured in comparable units for each observation, so that the estimates should not be much affected by changes in base definitions. To check robustness, however, the next two columns of Table 1 report estimates for smaller and more reliable samples of tax rates. In column 2, I exclude observations on six revenue categories for which base definitions are weakly related to the underlying economic activity from which the revenues are derived. ${ }^{12}$ In column 3, I additionally exclude all categories measured as specific rather than ad valorem (percentage) tax rates. In both cases, the OLS estimates of the tax interaction effects are essentially unchanged.

The obvious objection to these estimates of tax interactions is that tax rates in the various revenue categories are contemporaneously correlated among provinces, so that even controlling for fixed effects the error term in (11) is correlated with the average of competitors' tax rates ATR $_{i t c}$. To address this possibility, I instrument for ATR using population-weighted averages of a subset of the control variables $X_{j t c}$ of competing provinces. To keep the first stage parsimonious, I choose the two political variables Conservative and Social Democratic, and the population fraction Old as the excluded instruments for the two endogenous variables ATR and ATR $\times$ RCV on the righthand side of (11). The resulting two-stage least squares estimates are reported in Table 2, which is organized in a way parallel to the OLS estimates of Table 1. The bottom panel of the table reports some diagnostic statistics for the first-stage projections of ATR and ATR $\times$ RCV onto the instruments. The excluded instruments are jointly significant in all three regression samples used, as indicated by the reported $F$ statistics, albeit with somewhat greater explanatory power for the average tax rates faced by the receiving provinces. First-stage coefficients are unreported for the sake of brevity, but note that the average of Conservative exerts a significant negative effect on the average tax rate in both first-stage equations, conforming to intuition. The average fraction Old has a significant negative effect on ATR and a significant positive effect on ATR $\times$ RCV. On the basis of the Hansen $J$ statistics, I conclude that the instruments may reasonably be excluded from the second stage regressions in all three samples.

Relative to the OLS estimates, the principal difference to be discerned from the results in the top panel of Table 2 is that point estimates of the tax interaction effect ATR are now negative, and are insignificant in all cases. This is consistent with the notion that observed correlations

\footnotetext{
${ }^{12}$ The six are Commercial vehicle licences, Crown leases, Other oil and gas revenues, Property taxes, Lottery revenues, and Miscellaneous provincial-local tax revenues.
} 
among tax rates for non-receiving provinces reflect unobserved common shocks to tax rates, rather than any causal effect such as tax competition. The estimated coefficients for ATR $\times$ RCV remain however significantly positive in all cases. The tax interaction effect induced by the equalization grant formula is estimated to be about 40 or 50 per cent, depending on the sample used: that is, each one percentage point increase in the average of competitors' tax rates induces an increase in tax rates of equalization-receiving provinces that is about one-half percentage point higher than in non-receiving provinces. ${ }^{13}$

Because ATR is the population-weighted average of all other provinces' tax rates, the test that $\beta_{0}=0$ may lack power as a test for the absence of tax competition, if provinces react only to near neighbours' tax rates-and if these local interactions are missed by looking at national averages. In an alternative specification, not reported in the table, $A T R_{i t c}$ was constructed as the average of other provinces' tax rates, weighted by the product of their population and the inverse of the distance from the major city in each province and province $i$. This approach therefore assigns more weight to near neighbours' tax rates, which may be more relevant to tax competition (though less relevant to the Equalization effect). The estimates of $\beta_{0}$ and $\beta_{1}-\beta_{0}$ in this specification are nearly identical to those reported here, reflecting the high cross-sectional correlation of tax rates. Likewise, provinces may react to the tax rates of others, but only with a lag. In alternative unreported specifications, $A T R_{i t c}$ was replaced by one-year and two-year lagged values, and the key coefficient estimates were essentially unchanged.

As a final robustness check, I report in Table 3 estimates of the equalization tax interaction parameter ATR $\times \mathrm{RCV}$, estimated for various subsamples in which the revenue categories used are more directly comparable with each other. The leftmost column of figures reports the OLS estimated coefficient, while the next three columns report IV estimate and the $p$-values for the joint significance of the excluded instruments in the first stage for ATR $\times$ RCV and for the overidentification test. In three of five cases, the IV estimated equalization tax interaction is positive, in two cases significantly so. Interestingly, the IV estimates of the effect for personal income and business taxes are negative, the latter significantly. These results are at odds with those reported in Boadway and Hayashi (2001) for corporate taxes and in Esteller More and Sole Olle (2002) for personal income taxes. The difference may reflect differences in data, since the other two papers use effective tax rates calculated from the national income accounts, rather than my administrative data sources, or in the identification strategy employed. Indeed, my excluded instruments are insignificant in the first stage for personal income taxes, so the insignificance of the estimated second-stage coefficient is unsurprising. The estimated coefficient for the oil revenue categories is in contrast strongly positive, and perhaps implausibly large. In this case, the $J$ test statistic casts some doubt on the validity of the instruments. For these categories, an alternative identification strategy is available, described in the next section.

\section{Partial equalization}

I turn now to the reduced form estimates of the effect of equalization grants on taxes, estimated from the asymmetric changes in the equalization formula in the 1972-82 period. Recall that during 1974-76 only one-third of incremental deficiencies in oil and gas revenue capacity were equalized by federal transfers; during 1977-1981 partial equalization was extended to all non-renewable natural resource revenues (i.e. including mining taxes), and the equalization rate was increased

\footnotetext{
${ }^{13}$ Since the point estimate of the ATR coefficient is negative in all cases in Table 2 , the estimated combined effect of $A T R$ on tax rates in receiving provinces is itself insignificantly different from zero.
} 
to 50 per cent; in 1982 and thereafter, the equalization rate was 100 per cent, while the standard capacity was adjusted downward to keep transfer payments roughly constant. The reduced form prediction of our theory is that grant-receiving provinces should set higher tax rates in the affected categories under full equalization than under partial equalization. That is, the treatment group is the natural resource categories in the receiving provinces, while the available control groups for the analysis are the unaffected revenue categories and the provinces that did not receive equalization grants.

Table 4 presents the mean tax rates for the relevant combinations of provinces, revenue categories, and years. ${ }^{14}$ Observe that the average resource tax rate for receiving provinces during the full equalization period was 0.1054 , up from 0.0861 during the years of partial equalization. Over the same period, in contrast, resource tax rates in non-receiving provinces fell to 0.1012 from 0.1272. The difference in these changes is -0.0453 , which is one possible estimate of the effect of partial equalization on the affected tax categories and provinces.

Of course, the oil shocks of the 1970s had far-reaching economic impacts, which might in principle differ between receiving (generally poor) and non-receiving (rich) provinces in Canada, and which would therefore bias the difference-in-difference estimates. In this case, however, a natural control is available in the observed tax rates of the two groups of provinces for the nonresource revenue categories, for which there were no changes in the rate of equalization under the formula during the sample period. In this case, then, the identifying assumption is the weaker requirement that there were no unobserved shocks contemporaneous with the reform that affected resource tax rates relative to non-resource tax rates in equalization-receiving provinces, and that did not similarly affect relative tax rates in the non-receiving provinces. The lower part of Table 4 therefore reports the same calculations for the unaffected revenue categories. Observe that, in partial equalization years, non-resource tax rates in receiving provinces were 0.0203 higher than in full equalization years, compared to the corresponding difference over the same period in the nonreceiving provinces. The triple difference estimate of the effect of partial equalization is therefore $-0.0453-0.0203=-0.0656$, as reported in the last row of the table.

Table 5 next reports regression-based estimates of the triple difference effect, in order to obtain estimated standard errors and to facilitate robustness checks on the sample and on the controls for unobservables. The left column of numbers are estimates of the treatment effect of partial equalization from equation (12), while controlling for unobserved differences in tax rates between receiving and non-receiving provinces, affected and unaffected categories, pre- and post-reform years, and all bilateral interactions of these three aggregate binary indicators. The three rows of numbers in the table correspond to the three regression samples, as in the earlier tables. The first estimate therefore corresponds exactly to the estimate reported in Table 4 (the difference in the final digit is rounding error), and the reported heteroskedasticity-robust standard error indicates that the estimate is significantly different from zero at the 10 per cent level. The remaining estimates in the column show that the estimate is similar in the smaller samples, though estimated standard errors rise and statistical significance of the triple difference disappears.

While this procedure implements the standard triple difference estimator, considered e.g. by Gruber (1994), observe that the treatment effect $\gamma$ in (12) remains identified even when the unobserved component in tax rates is permitted to vary systematically among provinces, revenue categories, and years within the eight cells reported in Table 4. Since the data set constitutes an

\footnotetext{
${ }^{14}$ As noted above, partial equalization applied only to oil and gas revenues prior to 1977 , when it was extended to mineral revenues as well. Observations on the mining category are therefore split in two, and defined as part of the control group for 1974-76 and as part of the treatment group for 1977-81.
} 
unbalanced panel, moreover, the usual triple difference estimator may not be robust to such variation. For example, the data set includes some revenue categories for which tax rates are recorded only in the post-reform period 1982-2002. If the mean unobservable component of these tax rates differs between the receiving and non-receiving provinces, therefore, then the usual triple difference estimates are biased. To explore this possibility, I therefore also estimate a version of (12) that includes a full set of fixed effects for each province, year, and revenue category, as well as the approximately 1500 bilateral interactions between them. Thus the estimating equation becomes:

$$
E T R_{i t c}=\beta_{i c}^{1}+\beta_{i t}^{2}+\beta_{c t}^{3}+\gamma R C V_{i} \times \operatorname{RESOURCE}_{c} \times \operatorname{PARTIAL}_{t}+\epsilon_{i t c}
$$

where $\beta^{1}, \beta^{2}, \beta^{3}$ are vectors of all first-order and second-order fixed effects to be estimated. The resulting estimates of $\gamma$ are reported in the right column of Table 5. In all cases, the estimates are quite similar to the previous specification, but estimated standard errors somewhat smaller. The result is that the estimated treatment effect is in each sample significantly different from zero. Since the economic interpretation of the coefficient is clearest in the case of the sample of ad valorem taxes, I emphasize the last-reported estimate, which indicates that partial equalization was associated with tax rates about seven percentage points lower in the treated categories and provinces. I offer some further interpretation of the coefficient below.

\section{Conclusion: Interpreting the results}

In a federal system of government, subnational governments are ceded authority to collect taxes and determine levels of public spending. When this is so, attempts by federal authorities to promote regional equity through transfers may be hampered by the distortions in incentives for tax authorities at the subnational levels that such transfers create. Fiscal federalism therefore creates conflicts between efficiency and equity analogous to those existing in personal tax systems. Capacity equalization grant formulas are commonly adopted in many countries, in an attempt to minimize these incentive problems, compared to other systems of local revenue sharing. The notion is that calculating transfer entitlements indirectly, using differences in revenues calculated at deemed rather than actual tax rates, attenuates distortionary effects on the tax rates of recipient governments. But when measured tax bases respond negatively to tax rate increases, this formula may induce higher levels of distortionary taxation: increasing local tax rates causes measured tax bases to decline, as economic activity shifts to other regions of the country or to other, more lightly taxed forms-and so causes capacity equalization transfers to rise. Thus the grants in effect subsidize increases in distortionary taxes by equalization-receiving governments.

The empirical work reported in this paper suggests indeed that the tax-raising effect of equalization grants can be large. In a reduced form specification, it is estimated that the equilibrium impact of a policy reform that reduced the rate at which capacity differences were equalized from 100 to 50 per cent-in effect halving the size of the distortion-was to decrease the affected tax rates by about seven percentage points.

To get a further sense of the magnitude of the impact, it is useful to consider also the equilibrium implications of the tax-interaction effect of equalization grants, estimated from the structural model of tax reaction functions. Consistent with the structural estimates of Section 5, suppose that the slope of the best response function of provinces that do not receive equalization grants is zerothat is, there is no tax competition effect-whereas the slope of reaction functions in receiving provinces is 0.5 because of the equalization effect. Applying equation (8) with the point estimates $\beta(0)=0$ and $\beta(\theta)=\theta / 2$, the marginal effect of the equalization rate on the equilibrium tax rate 
in grant-receiving provinces may then be shown to be

$$
\frac{\partial \bar{y}_{R}(\theta)}{\partial \theta}=\frac{\bar{y}}{2-\theta \omega_{R}}
$$

where $\bar{y}_{R}$ is the average equilibrium tax rate in grant-receiving provinces, $\bar{y}$ the national average or target tax rate, and $\omega_{R}$ the population weight of the aggregate of receiving provinces in the formula. Since the population share of the Canadian receiving provinces is about one-half, and the average tax rate in my sample is about 0.2 , a rough estimate of the marginal effect of equalization on tax rates at $\theta=1$, based on the structural estimates, is $\partial y_{R} / \partial \theta=.2 / 1.5=2 / 15$.

In other words, based on the structural estimates, a reduction in the equalization rate from 100 to 50 per cent is estimated to reduce affected tax rates by about $1 / 15 \approx 0.067$-a very rough approximate calculation that is nevertheless remarkably similar to the reduced form estimate from the actual policy reform, whose estimator relies on an entirely different identification strategy. Together with the evidence from various countries in the previous literature, this might be taken as fairly robust evidence of a meaningful effect of equalization grants on subnational tax policies.

Another way to evaluate the plausibility of the structural estimates of $\beta_{0}$ and $\beta_{1}$ is to ask whether they are consistent with reasonable values for the tax base and population parameters that are the primitives of the theoretical model. As noted, the estimates are consistent with $\beta_{0}=0$, which holds in the theoretical model if and only if $b=0$, i.e. no spillovers from tax rates to tax bases in other provinces. But $b=0$ implies that the tax-interaction effect of equalization in the theoretical model is, using equation (4),

$$
\beta_{i 1}-\beta_{i 0}=\frac{1}{2}\left(1-\omega_{i}\right)
$$

independent of the own-tax responsiveness parameter $a$. Since the average population share of receiving provinces in the sample is 6.1 per cent, the average equalization effect predicted by the theoretical model is $\beta_{1}-\beta_{0}=0.47$, well within the confidence interval actually estimated. In other words, both of the slope parameters estimated are consistent with tax interactions driven by intergovernmental transfer considerations, but not by horizontal tax competition per se.

In the partial equilibrium theoretical model of Smart (1998), the tax-raising effect of equalization results in equilibrium tax rates that are above second-best optimal levels, and so a loss in welfare for the affected consumers. But Köthenbürger (2002) shows that, in the presence of horizontal tax competition, equalization can induce an increase in Nash-equilibrium tax rates that increases consumer welfare. Indeed, Bucovetsky and Smart (2006) show that, when tax competition effects are strong enough, an equalization grant may in a wide variety of settings induce subnational governments to independently choose tax rates that are optimal from a national perspective. My estimates suggest however that, for the tax systems of the Canadian provinces at least, the effects of tax competition within the federation on tax rates are negligible, so that equalization grants cannot be interpreted as (however unintentional) a corrective device for tax competition, and the tax-raising effect of the grants is deleterious to consumer welfare. 


\section{Data appendix}

The principal source of data for the analysis is an administrative data set recording tax bases and revenues of the 10 provinces for the 1972-2002 period-excluding 1973 and 1981, when tax base data are missing - which is used by the federal Department of Finance to compute each province's transfer entitlements under the Equalization program. The ratio of tax revenues to tax base for each province, year, and revenue category defines the respective effective tax rate, which is the dependent variable for the analysis.

A total of 35 separate revenue categories have been used in the formula since 1972, but I delete a number of these categories a priori, since the ad hoc way in which tax bases of provinces are measured renders the resulting effective tax rates highly unreliable as measures of actual provincial tax policies. For example, the tax base for Hospital and Medical Insurance Premiums is measured as a weighted average of the number of persons in various income categories in each provincewith the weights changing frequently over the sample period-despite the fact that some provinces levy payroll taxes for medical care and many levy no such taxes whatsoever. Likewise, I exclude Succession Duties, for which the base definition is arbitrary, and which all the provinces phased out in any case during the 1970s. I also exclude the Water Power category, for which the base is nominally measured in kilowatt-hours, but with numerous ad hoc adjustments over the years that are apparently designed to affect the entitlement of one province, Newfoundland. Also excluded are a small number of sui generis categories, for which in many years more than 70 per cent of the national base accrues to a single province. ${ }^{15}$ Such categories are known to create special incentive problems for the provinces (e.g., Courchene, 1984) that are quite distinct from the subject of this paper. I also delete some observations while retaining others for the same base: Crown Leases for the period 1972-86, when the base was defined to be actual revenues of the provinces, so that the implied effective tax rates are all identically equal to unity, and Other Oil and Gas in 1972-76 and Forestry in 1992-94, when the scale of tax capacities in the data differ markedly from the adjacent years. These anomalies presumably reflect either undocumented changes in the base definitions or simple data entry errors. Summary statistics for the tax rates used in the analysis are presented in Table A1.

\footnotetext{
${ }^{15}$ These categories are known as Potash, Newfoundland Offshore Resources, and Nova Scotia Offshore Resources. On the same grounds, I exclude Exported Natural Gas, the vast majority of which accrues to two provinces, neither of which receives equalization grants.
} 
Table 1: OLS estimates of the effect of equalization on tax interactions

\begin{tabular}{lccc} 
& $\begin{array}{c}\text { All revenue } \\
\text { categories }\end{array}$ & $\begin{array}{c}\text { Unvarying base } \\
\text { definitions }\end{array}$ & $\begin{array}{c}\text { Ad valorem } \\
\text { taxes }\end{array}$ \\
\hline ATR & $0 \cdot 69^{* * *}$ & $0 \cdot 69^{* * *}$ & $0 \cdot 71^{* * *}$ \\
ATR $\times$ RCV & $(0 \cdot 06)$ & $(0 \cdot 06)$ & $(0 \cdot 06)$ \\
RCV & $0 \cdot 44^{* * *}$ & $0 \cdot 44^{* * *}$ & $0 \cdot 44^{* * *}$ \\
YOUNG & $(0 \cdot 05)$ & $(0 \cdot 06)$ & $(0 \cdot 06)$ \\
& $-0 \cdot 02$ & $-0 \cdot 08^{* * *}$ & $-0 \cdot 02$ \\
OLD & $(0 \cdot 02)$ & $(0 \cdot 02)$ & $(0 \cdot 03)$ \\
& $0 \cdot 11$ & $0 \cdot 31^{*}$ & $0 \cdot 51^{* *}$ \\
GDP per capita & $(0 \cdot 14)$ & $(0 \cdot 16)$ & $(0 \cdot 20)$ \\
& $-0 \cdot 13$ & $-0 \cdot 08$ & $1 \cdot 49^{* *}$ \\
Conservative & $(0 \cdot 47)$ & $(0 \cdot 61)$ & $(0 \cdot 71)$ \\
& $-2 \cdot 64^{* *}$ & $-2 \cdot 65^{*}$ & $-2 \cdot 50$ \\
Social democratic & $(1 \cdot 09)$ & $(1 \cdot 41)$ & $(1 \cdot 88)$ \\
& $0 \cdot 01^{*}$ & $0 \cdot 01$ & $0 \cdot 00$ \\
Observations & $(0 \cdot 00)$ & $(0 \cdot 01)$ & $(0 \cdot 01)$ \\
& $0 \cdot 01^{*}$ & $0 \cdot 02^{* *}$ & $0 \cdot 01$ \\
& $(0 \cdot 01)$ & $(0 \cdot 01)$ & $(0 \cdot 01)$ \\
& 6017 & 4665 & 3241 \\
\hline
\end{tabular}

Notes: Robust standard errors in parentheses.

${ }^{*}$ significant at $10 \%$ level; ${ }^{* *}$ significant at $5 \%$ level; ${ }^{* * *}$ significant at $1 \%$ level. 
Table 2: IV estimates of the effect of equalization on tax interactions

\begin{tabular}{ccc}
$\begin{array}{c}\text { All revenue } \\
\text { categories }\end{array}$ & $\begin{array}{c}\text { Unvarying base } \\
\text { definitions }\end{array}$ & $\begin{array}{c}\text { Ad valorem } \\
\text { taxes }\end{array}$ \\
\hline
\end{tabular}

A. IV estimates

\begin{tabular}{lccc} 
ATR & $-0 \cdot 67$ & $-0 \cdot 37$ & $-1 \cdot 18$ \\
& $(0 \cdot 77)$ & $(0 \cdot 79)$ & $(1 \cdot 16)$ \\
ATR $\times$ RCV & $0 \cdot 40^{* * *}$ & $0 \cdot 37^{* * *}$ & $0 \cdot 51^{* * *}$ \\
RCV & $(0 \cdot 15)$ & $(0 \cdot 14)$ & $(0 \cdot 14)$ \\
YOUNG & $-0 \cdot 05^{*}$ & $-0 \cdot 06$ & $-0 \cdot 03$ \\
& $(0 \cdot 03)$ & $(0 \cdot 04)$ & $(0 \cdot 05)$ \\
OLD & $0 \cdot 22$ & $0 \cdot 43^{* *}$ & $0 \cdot 59^{* *}$ \\
& $(0 \cdot 14)$ & $(0 \cdot 17)$ & $(0 \cdot 27)$ \\
GDP per capita & $-0 \cdot 12$ & $-0 \cdot 07$ & $1 \cdot 54^{* *}$ \\
& $(0 \cdot 43)$ & $(0 \cdot 57)$ & $(0 \cdot 63)$ \\
Conservative & $-0 \cdot 63$ & $-0 \cdot 52$ & $-0 \cdot 10$ \\
& $(1 \cdot 34)$ & $(1 \cdot 70)$ & $(2 \cdot 95)$ \\
Social democratic & $0 \cdot 00$ & $0 \cdot 00$ & $-0 \cdot 01$ \\
& $(0 \cdot 00)$ & $(0 \cdot 01)$ & $(0 \cdot 01)$ \\
Observations & $0 \cdot 01$ & $0 \cdot 01$ & $-0 \cdot 00$ \\
& $(0 \cdot 01)$ & $(0 \cdot 01)$ & $(0 \cdot 01)$ \\
B. First-stage diagnostics & 6017 & 4665 & 3241 \\
F-statistic of excluded instruments: & & & \\
ATR & & & \\
ATR $\times$ RCV & $4 \cdot 62^{* * *}$ & $5 \cdot 69^{* * *}$ & $3 \cdot 77^{* *}$ \\
Hansen $J$-statistic & {$[\cdot 004]$} & {$[\cdot 000]$} & {$[\cdot 011]$} \\
& $40 \cdot 39^{* * *}$ & $38 \cdot 40^{* * *}$ & $38 \cdot 80^{* * *}$ \\
\hline
\end{tabular}

Notes: Robust standard errors in parentheses and $p$-values in brackets. For each observation, instruments for ATR and ATR $\times$ RCV are the population weighted averages of Conservative, Social Democratic, and Old in the other provinces.

${ }^{*}$ significant at $10 \%$ level; ${ }^{* *}$ significant at $5 \%$ level; ${ }^{* * *}$ significant at $1 \%$ level. 
Table 3: Further IV estimates

OLS

Estimated ATR $\times$ RCV

Revenue category

Personal income

Business taxes

Excise taxes

Oil royalties

Other taxes

$\begin{array}{cccc}\begin{array}{c}\text { OLS } \\ \text { timated }\end{array} & \begin{array}{c}\text { Estimated } \\ \text { ATR } \times \text { RCV }\end{array} & \begin{array}{c}\text { IV } \\ p \text {-value } \\ \text { first stage }\end{array} & \begin{array}{c}p \text {-value } \\ \text { Hansen } J\end{array} \\ -0.237^{* * *} & -0.847 & 0.160 & 0.225 \\ (0.063) & (0.520) & & 0.907 \\ 0.061 & -1.361^{* *} & 0.000 & 0.375 \\ (0.063) & (0.574) & & 0.002 \\ 0.447^{* * *} & 0.450^{*} & & \\ (0.064) & (0.256) & 0.000 & 0.337 \\ 0.511^{* * *} & 1.449^{* * *} & & \\ (0.110) & (0.423) & 0.000 & \\ -0.282^{* * *} & 0.103 & & \\ (0.074) & (0.212) & & \end{array}$

Estimated
ATR $\times$ RCV

IV

-value

first stage

$p$-value Hansen $J$

Notes: Robust standard errors in parentheses. The instruments are the same as in Table 2.

* significant at 10\% level; ** significant at 5\% level; *** significant at $1 \%$ level. 
Table 4: Equalization reform and effective tax rates

Mean effective tax rates:

Revenue category and province type

Resource royalties, equalization provinces

Resource royalties, other provinces

Other taxes, equalization provinces

Other taxes, other provinces

\begin{tabular}{|c|c|c|c|}
\hline $\begin{array}{l}\text { Number of } \\
\text { observations }\end{array}$ & $\begin{array}{l}\text { Full equal- } \\
\text { ization years }\end{array}$ & $\begin{array}{l}\text { Partial equal- } \\
\text { ization years }\end{array}$ & $\begin{array}{l}\text { Difference } \\
\text { over time }\end{array}$ \\
\hline 423 & 0.1054 & 0.0861 & -0.0193 \\
\hline 485 & 0.1012 & 0.1272 & 0.026 \\
\hline \multicolumn{3}{|c|}{ Difference in difference: } & -0.0453 \\
\hline 3550 & 0.2055 & 0.2562 & 0.0507 \\
\hline 1560 & 0.1598 & 0.1902 & 0.0304 \\
\hline \multicolumn{3}{|c|}{$\begin{array}{r}\text { Difference in difference: } \\
\text { Triple difference : }\end{array}$} & 0.0203 \\
\hline
\end{tabular}

Table 5: Triple difference estimates of the effect of partial equalization

Controls for unobservables:

\begin{tabular}{lrr} 
Sample & $\begin{array}{r}\text { Aggregate } \\
\text { interactions }\end{array}$ & $\begin{array}{r}\text { All bilateral } \\
\text { interactions }\end{array}$ \\
\hline All revenue categories & $-0.0654^{*}$ & $-0.0463^{* *}$ \\
Unvarying base definitions & {$[0.0382]$} & {$[.0234]$} \\
& -0.0579 & $-0.0626^{* *}$ \\
Ad valorem taxes & {$[.0448]$} & {$[.0294]$} \\
& -0.0709 & $-0.0721^{*}$ \\
& {$[.0609]$} & {$[.0414]$}
\end{tabular}

Notes: Robust standard errors in brackets.

${ }^{*}$ significant at $10 \%$ level; ${ }^{* *}$ significant at 5\% level; ${ }^{* * *}$ significant at $1 \%$ level. 
Table A1: Effective tax rates: Summary statistics

\begin{tabular}{|c|c|c|c|c|c|}
\hline Category & ad valorem & mean & std. dev. & obs. & years \\
\hline Personal income taxes & $\mathrm{x}$ & $0 \cdot 57$ & $\cdot 129$ & 285 & 1972-2002 \\
\hline \multicolumn{6}{|l|}{ Business taxes: } \\
\hline Business income taxes & $\mathrm{x}$ & $0 \cdot 11$ & .072 & 285 & 1972-2002 \\
\hline Capital tax & $\mathrm{x}$ & $0 \cdot 00$ & .002 & 285 & 1972-2002 \\
\hline Sales taxes & & $0 \cdot 11$ & .058 & 275 & 1972-2002 \\
\hline \multicolumn{6}{|l|}{ Excise taxes: } \\
\hline Tobacco & & 0.05 & .028 & 285 & 1972-2002 \\
\hline Gasoline & $\mathrm{x}$ & $0 \cdot 77$ & .518 & 285 & 1972-2002 \\
\hline Diesel & $\mathrm{x}$ & 0.93 & 659 & 285 & 1972-2002 \\
\hline Race tracks & $\mathrm{x}$ & $0 \cdot 10$ & .055 & 284 & 1972-2002 \\
\hline \multicolumn{6}{|l|}{ Alcohol taxes and markups: } \\
\hline Alcohol total & & $0 \cdot 19$ & .075 & 110 & 1992-2002 \\
\hline Spirits & & 0.28 & .053 & 175 & 1972-1991 \\
\hline Wine & & $0 \cdot 23$ & .072 & 175 & 1972-1991 \\
\hline Beer & & $0 \cdot 13$ & .054 & 175 & 1972-1991 \\
\hline \multicolumn{6}{|l|}{ Forestry: } \\
\hline value-added base & $\mathrm{x}$ & $0 \cdot 22$ & $\cdot 149$ & 159 & 1972-1991 \\
\hline volume base & & $0 \cdot 16$ & $\cdot 317$ & 90 & 1992-2002 \\
\hline \multicolumn{6}{|l|}{ Oil royalties: } \\
\hline New/NORP oil & $\mathrm{x}$ & $0 \cdot 11$ & .067 & 99 & 1982-2002 \\
\hline Old oil & $\mathrm{x}$ & $0 \cdot 18$ & $\cdot 152$ & 153 & 1972-2002 \\
\hline Heavy oil & $\mathrm{x}$ & $0 \cdot 12$ & .065 & 41 & 1982-2002 \\
\hline Mined oil & $\mathrm{x}$ & $0 \cdot 07$ & .049 & 29 & 1972-2002 \\
\hline \multicolumn{6}{|l|}{ Other non-renewable resources: } \\
\hline Domestic natural gas & & $0 \cdot 06$ & .084 & 129 & 1972-2002 \\
\hline Crown leases & $\mathrm{x}$ & $0 \cdot 30$ & $\cdot 282$ & 82 & 1987-2002 \\
\hline Other oil \& gas & & 0.03 & .041 & 130 & 1972-2002 \\
\hline Mining & $\mathrm{x}$ & $0 \cdot 05$ & .087 & 285 & 1972-2002 \\
\hline \multicolumn{6}{|l|}{ Other ad valorem taxes: } \\
\hline Insurance premiums & $\mathrm{x}$ & 0.03 & $\cdot 014$ & 285 & 1972-2002 \\
\hline Payroll taxes & $\mathrm{x}$ & 0.01 & .011 & 207 & 1972-2002 \\
\hline Property taxes & $\mathrm{x}$ & 0.02 & .012 & 285 & 1972-2002 \\
\hline Lottery revenues & $\mathrm{x}$ & $0 \cdot 00$ & .001 & 285 & 1972-2002 \\
\hline Misc. provincial-local taxes & $\mathrm{x}$ & $0 \cdot 12$ & .039 & 285 & 1972-2002 \\
\hline
\end{tabular}




\section{References}

Baretti, Christian, Bernd Huber, and Karl Lichtblau (2001) 'A tax on tax revenue: The incentive effects of equalizing transfers: Evidence from Germany.' International Tax and Public Finance $9,631-649$

Bird, Richard, and Michael Smart (2002) 'Intergovernmental fiscal transfers: International lessons for developing countries.' World Development 30, 899-912

Boadway, Robin, and Masayoshi Hayashi (2001) 'An empirical analysis of intergovernmental tax interaction: The case of business income taxes in Canada.' Canadian Journal of Economics 34, 481503

Boadway, Robin W., and Frank R. Flatters (1982) 'Efficiency and equalization payments in a federal system of government: A synthesis and extension of recent results.' Canadian Journal of Economics 15, 613-633

Bucovetsky, Sam, and Michael Smart (2006) 'The efficiency consequences of local revenue equalization: Tax competition and tax distortions.' Journal of Public Economic Theory 8, 119-144

Buettner, Thiess (2005) 'The incentive effect of fiscal equalization transfers on tax policy.' Journal of Public Economics 90, 477-497

Card, David, and Abigail Payne (2002) 'School finance reform, the distribution of school spending, and the distribution of student test scores.' Journal of Public Economics 83, 49-82

Courchene, Thomas J. (1984) Equalization Payments: Past, Present and Future (Toronto: Ontario Economic Council)

Dahlby, Bev, and Neil Warren (2003) 'Fiscal incentive effects of the Australian equalization system.' Economic Record 79, 434-445

Egger, Peter, Marko Koethenbuerger, and Michael Smart (2006) 'Do fiscal transfers alleviate business tax competition? evidence from Germany.' Working Paper, University of Munich

Esteller More, Alex, and Albert Sole Olle (2002) 'An empirical analysis of vertical tax externalities: The case of personal income taxation in Canada.' International Tax and Public Finance 9, 235-257

Gruber, Jonathan (1994) 'The incidence of mandated maternity benefits.' American Economic Review $84,622-641$

Knight, Brian (2002) 'Endogenous federal grants and crowd-out of state government spending: Theory and evidence from the federal highway aid program.' American Economic Review 92, 7192

Köthenbürger, Marko (2002) 'Tax competition and fiscal equalization.' International Tax and Public Finance 9, 391-408

Smart, Michael (1998) 'Taxation and deadweight loss in a system of intergovernmental transfers.' Canadian Journal of Economics 31, 189-206 


\section{CESifo Working Paper Series}

(for full list see www.cesifo-group.de)

1864 Sascha O. Becker and Marc-Andreas Muendler, The Effect of FDI on Job Separation, December 2006

1865 Christos Kotsogiannis and Robert Schwager, Fiscal Equalization and Yardstick Competition, December 2006

1866 Mikael Carlsson, Stefan Eriksson and Nils Gottfries, Testing Theories of Job Creation: Does Supply Create Its Own Demand?, December 2006

1867 Jacques H. Drèze, Charles Figuières and Jean Hindriks, Voluntary Matching Grants Can Forestall Social Dumping, December 2006

1868 Thomas Eichner and Marco Runkel, Corporate Income Taxation of Multinationals and Unemployment, December 2006

1869 Balázs Égert, Central Bank Interventions, Communication and Interest Rate Policy in Emerging European Economies, December 2006

1870 John Geweke, Joel Horowitz and M. Hashem Pesaran, Econometrics: A Bird's Eye View, December 2006

1871 Hans Jarle Kind, Marko Koethenbuerger and Guttorm Schjelderup, Taxation in TwoSided Markets, December 2006

1872 Hans Gersbach and Bernhard Pachl, Cake Division by Majority Decision, December 2006

1873 Gunther Schnabl, The Evolution of the East Asian Currency Baskets - Still Undisclosed and Changing, December 2006

1874 Horst Raff and Michael J. Ryan, Firm-Specific Characteristics and the Timing of Foreign Direct Investment Projects, December 2006

1875 Jukka Pirttilä and Håkan Selin, How Successful is the Dual Income Tax? Evidence from the Finnish Tax Reform of 1993, December 2006

1876 Agnieszka Stążka, Sources of Real Exchange Rate Fluctuations in Central and Eastern Europe - Temporary or Permanent?, December 2006

1877 Xavier Calsamiglia, Teresa Garcia-Milà and Therese J. McGuire, Why do Differences in the Degree of Fiscal Decentralization Endure?, December 2006

1878 Natacha Gilson, How to be Well Shod to Absorb Shocks? Shock Synchronization and Joining the Euro Zone, December 2006 
1879 Scott Alan Carson, Modern Health Standards for Peoples of the Past: Biological Conditions by Race in the American South, 1873 - 1919, December 2006

1880 Peter Huber, Michael Pfaffermayr and Yvonne Wolfmayr, Are there Border Effects in the EU Wage Function?, December 2006

1881 Harry Flam and Håkan Nordström, Euro Effects on the Intensive and Extensive Margins of Trade, December 2006

1882 Panu Poutvaara and Mikael Priks, Hooliganism in the Shadow of the 9/11 Terrorist Attack and the Tsunami: Do Police Reduce Group Violence?, December 2006

1883 Ruud A. de Mooij and Gaëtan Nicodème, Corporate Tax Policy, Entrepreneurship and Incorporation in the EU, December 2006

1884 Johannes Becker and Clemens Fuest, Corporate Tax Policy and International Mergers and Acquisitions - Is the Tax Exemption System Superior?, January 2007

1885 Momi Dahan and Udi Nisan, The Effect of Benefits Level on Take-up Rates: Evidence from a Natural Experiment, January 2007

1886 José García-Solanes, Francisco I. Sancho-Portero and Fernando Torrejón-Flores, Beyond the Salassa-Samuelson Effect in some New Member States of the European Union, January 2007

1887 Peter Egger, Wolfgang Eggert and Hannes Winner, Saving Taxes Through Foreign Plant Ownership, January 2007

1888 Timothy J. Goodspeed and Andrew Haughwout, On the Optimal Design of Disaster Insurance in a Federation, January 2007

1889 Wim Groot, Henriëtte Maassen van den Brink and Bernard van Praag, The Compensating Income Variation of Social Capital, January 2007

1890 Bas Jacobs, Ruud A. de Mooij and Kees Folmer, Analyzing a Flat Income Tax in the Netherlands, January 2007

1891 Hans Jarle Kind, Guttorm Schjelderup and Frank Stähler, Newspapers and Advertising: The Effects of Ad-Valorem Taxation under Duopoly, January 2007

1892 Erkki Koskela and Rune Stenbacka, Equilibrium Unemployment with Outsourcing under Labour Market Imperfections, January 2007

1893 Maarten Bosker, Steven Brakman, Harry Garretsen, Herman de Jong and Marc Schramm, The Development of Cities in Italy 1300 - 1861, January 2007

1894 Michel Beine, Oscar Bernal, Jean-Yves Gnabo and Christelle Lecourt, Intervention Policy of the BoJ: A Unified Approach, January 2007 
1895 Robert S. Chirinko and Daniel J. Wilson, State Investment Tax Incentives: A Zero-Sum Game?, January 2007

1896 Theo S. Eicher and Oliver Roehn, Sources of the German Productivity Demise Tracing the Effects of Industry-Level ICT Investment, January 2007

1897 Helge Berger, Volker Nitsch and Tonny Lybek, Central Bank Boards around the World: Why does Membership Size Differ?, January 2007

1898 Gabriel Felbermayr and Wilhelm Kohler, Does WTO Membership Make a Difference at the Extensive Margin of World Trade?, January 2007

1899 Benno Torgler and Friedrich Schneider, The Impact of Tax Morale and Institutional Quality on the Shadow Economy, January 2007

1900 Tomer Blumkin and Efraim Sadka, On the Desirability of Taxing Charitable Contributions, January 2007

1901 Frederick van der Ploeg and Reinhilde Veugelers, Higher Education Reform and the Renewed Lisbon Strategy: Role of Member States and the European Commission, January 2007

1902 John Lewis, Hitting and Hoping? Meeting the Exchange Rate and Inflation Criteria during a Period of Nominal Convergence, January 2007

1903 Torben M. Andersen, The Scandinavian Model - Prospects and Challenges, January 2007

1904 Stephane Dees, Sean Holly, M. Hashem Pesaran and L. Vanessa Smith, Long Run Macroeconomic Relations in the Global Economy, January 2007

1905 Richard Jong-A-Pin and Jakob De Haan, Political Regime Change, Economic Reform and Growth Accelerations, January 2007

1906 Sascha O. Becker and Peter H. Egger, Endogenous Product versus Process Innovation and a Firm's Propensity to Export, February 2007

1907 Theo S. Eicher, Chris Papageorgiou and Oliver Roehn, Unraveling the Fortunates of the Fortunate: An Iterative Bayesian Model Averaging (IBMA) Approach, February 2007

1908 Liliana E. Pezzin, Robert A. Pollak and Barbara S. Schone, Efficiency in Family Bargaining: Living Arrangements and Caregiving Decisions of Adult Children and Disabled Elderly Parents, February 2007

1909 Christian Keuschnigg and Soren Bo Nielsen, Self-Selection and Advice in Venture Capital Finance, February 2007

1910 Rune Jansen Hagen and Gaute Torsvik, Irreversible Investments, Dynamic Inconsistency and Policy Convergence, February 2007 
1911 Eric A. Hanushek and Ludger Woessmann, The Role of School Improvement in Economic Development, February 2007

1912 Bernard M. S. van Praag, Perspectives from the Happiness Literature and the Role of New Instruments for Policy Analysis, February 2007

1913 Volker Grossmann and Thomas M. Steger, Growth, Development, and Technological Change, February 2007

1914 Margarita Katsimi and Thomas Moutos, Human Capital and the Feldstein-Horioka Puzzle, February 2007

1915 Oliver Roehn, Theo S. Eicher and Thomas Strobel, The Ifo Industry Growth Accounting Database, February 2007

1916 Ian Babetskii, Aggregate Wage Flexibility in Selected New EU Member States, February 2007

1917 Burkhard Heer, Alfred Maussner and Paul D. McNelis, The Money-Age Distribution: Empirical Facts and Limited Monetary Models, February 2007

1918 Yin-Wong Cheung, Menzie D. Chinn and Eijii Fujii, The Overvaluation of Renminbi Undervaluation, February 2007

1919 Jim Malley, Apostolis Philippopoulos and Ulrich Woitek, To React or Not? Fiscal Policy, Volatility and Welfare in the EU-3, February 2007

1920 Mattias Polborn, Competing for Recognition through Public Good Provision, February 2007

1921 Lars P. Feld and Benno Torgler, Tax Morale after the Reunification of Germany: Results from a Quasi-Natural Experiment, February 2007

1922 Robert S. Chirinko and Huntley Schaller, Fundamentals, Misvaluation, and Investment: The Real Story, February 2007

1923 Benno Torgler and Friedrich Schneider, Shadow Economy, Tax Morale, Governance and Institutional Quality: A Panel Analysis, February 2007

1924 Adrian Pagan and M. Hashem Pesaran, On Econometric Analysis of Structural Systems with Permanent and Transitory Shocks and Exogenous Variables, February 2007

1925 Hans-Werner Sinn, The Welfare State and the Forces of Globalization, February 2007

1926 Michael Smart, Raising Taxes through Equalization, February 2007 